\title{
Perilaku Pencarian Informasi Pertanian melalui Media Online pada Kelompok Petani Jahe
}

\author{
Ope Destrian ${ }^{1}$, Uud Wahyudin ${ }^{2}$, dan Slamet Mulyana ${ }^{3}$ \\ ${ }_{1,2,3}$ Universitas Padjadjaran
}

\begin{abstract}
ABSTRAK
Artikel ini menelusuri perilaku pencarian informasi pertanian melalui media online pada petani jahe, Kelompok Tani Jahe Putri Mandiri Di Desa Putri Dalem Kecamatan Jatitujuh Kabupaten Majalengka. Penelitian ini bertujuan untuk mengetahui mengapa petani jahe Putri Mandiri membutuhkan informasi pertanian melalui media online; bagaimana pola komunikasi yang dilakukan petani jahe putri mandiri dalam mengimplementasikan pencarian informasi pertanian; dan peranan informasi dalam pemecahan masalah. Metode yang digunakan pada penelitian ini yaitu kualitatif dengan pendekatan studi kasus. Berdasarkan hasil penelitian diketahui bahwa kebutuhan informasi petani Jahe Putri Mandiri menjadikan media online sebagai pemenuhan kebutuhan informasi dalam Pencarian Informasi Pertanian dan penanggulangan penanaman jahe dengan sistem polybag. Kesimpulan dalam penelitian ini, yaitu: Mereka merasa belum cukup mendapatkan penyuluhan dalam pengetahuan pertanian, sehingga ketua kelompok perlu untuk memperbaiki pola bercocok tanam jahe melalui media online; Petani mendapatkan informasi pertanian yang dibutuhkan melalui media online yaitu Google, Yahoo, Facebook, dan Twitter dan selanjutnya mendapatkan bantuan dari pakar pertanian di bidang jahe gajah; Pola komunikasi yang dilakukan oleh petani dan ketua kelompok petani setiap hari selalu menggunakan media online; Penggunaan Media online terhadap petani sangat cocok untuk diimplementasikan tentang tanaman jahe gajah pada Desa Putri Dalem, Jatitujuh, Majalengka; Informasi yang diperoleh petani melalui media online. Selanjutnya petani mendiskusikan dengan kelompok petani jahe di Indonesia melalui media online, setelah itu mereka mendiskusikannya lagi dalam kelompok tani jahe putri mandiri terutama yang berkaitan dengan cara-cara penanggulangan permasalahan jahe gajah.
\end{abstract}

Kata-kata Kunci: Lingkungan; media online; pakar petani; perilaku pencarian informasi; petani jahe

\section{Behavior of Agricultural Information Search through Online Media in Ginger Farmer Group}

\begin{abstract}
This study analyze the Behavior of Agricultural Information Search through Online media in Group of Putri Mandiri Ginger Farmerm Putri Dalem Village, Jatitujuh, Majalengka. This research aims to knowing Why Putri Mandiri ginger farmers need agricultural information through online media; how patterns of communication conducted independently Putri Mandiri ginger farmers in implementing agricultural and information search; and role of information in problem solving. The method used in this study is a qualitative with case study approach. Based on the survey results revealed that the information needs of Putri Mandiri ginger farmers make online media as the fulfillment of the information in search of Agricultural Information and countermeasures of planting ginger with polybag system. The conclusion of this study, namely: They have not had enough to get extension in agricultural knowledge, so that the head of the group need to improve cropping patterns ginger through online media; google, yahoo, facebook, and twitter and then get help from agricultural specialist in the field of elephant ginger; The pattern of communications made by farmer and farmer group leaders every day always using online media; The use of online media to farmers is very suitable for implementation of the elephant ginger plant in Putri Dalem village, Jatitujuh, Majalengka; The information obtained by farmers is through online media. Furthermore, farmers discussed with group leaders ginger farmer in Indonesia in social media, after which they discussed it again in Putri Mandiri ginger farmers group, especially with regard to ways of tackling problems elephant ginger.
\end{abstract}

Keywords: Environtment; farmer specialist; ginger farmer; information seeking behavior; online media

Korespondensi: Ope Destrian, M.I.Kom. Universitas Padjadjaran. Jalan Raya Bandung-Sumedang KM. 21 Jatinangor 45363. Email: opedestrian81@gmail.com

Submitted: June 2017, Accepted: April 2018, Published: June 2018

ISSN: 2303-2006 (print), ISSN: 2477-5606 (online). Website: http://jurnal.unpad.ac.id/jkk

Terakreditasi Kemenristekdikti RI SK No. 48a/E/KPT/2017 


\section{PENDAHULUAN}

Pembangunan pertanian saat ini lebih ditekankan pada peningkatan kualitas sumber daya manusia. Bedasarkan peraturan menteri komunikasi dan informatika Republik Indonesia No.08/PER/M.KOMINFO/6/2016 tentang pedoman pengembangan dan pemberdayaan lembaga komunikasi sosial, tanggal 1 Juni 2010 KIM (Kelompok Informasi Masyarakat) atau kelompok sejenis lainnya adalah kelompok yang dibentuk oleh, dari, untuk masyarakat secara mandiri dan kreatif yang aktivitasnya melakukan pengelolaan informasi dan pemberdayaan masyarakat dalam rangka meningkatkan nilai tambah (KIM Provinsi Lampung, 2014).

Saat ini perkembangan teknologi komunikasi dan informasi kian berkembang pesat. Seperti yang dikemukakan oleh Yusup dan Saepudin bahwa tidak ada seorang pun di dunia ini yang bisa menghitung banyaknya informasi yang pernah dilahirkan karena jumlah informasi yang terus berkembang tak terbatas seiring dengan semakin banyaknya jumlah manusia yang dilahirkan dan semakin banyaknya gagasan manusia yang melahirkan informasi (2017: 79). Pemanfaatan teknologi komunikasi dan informasi dapat dijadikan alternatif tepat untuk dimanfaatkan oleh para petani sebagai media untuk berkomunikasi dengan masyarakat petani. Akar permasalahan dari petani jahe adalah perilaku pencarian informasi merupakan konsep kebutuhan informasi. Petani juga merupakan hal yang perlu diperhatikan untuk melihat komunikasi petani yang dilakukan antar petani. Sedangkan menurut Levis, L. R. dan Y. L. Henuk (2005: 3) adanya strategi pendekatan komunikasi yang horizontal, konvergen, transaksional dan partisipatif dalam pertanian sehingga bisa mempercepat alih teknologi dan adopsi inovasi program serta akan menggerakkan partisipasi petani dalam program-program pembangunan pertanian. Begitu juga komunikasi pertanian menjadi sebuah kebutuhan dalam tugas seorang penyuluh pertanian atau siapapun yang mempunyai kemampuan dan kemauan untuk memajukan pertanian. Sehingga semakin jelas bahwa peranan komunikasi pertanian ini menjadi sangat penting dalam memajukan kesejahteraan para petani beserta keluarga tani.

Bentuk pencarian informasi dan pemilihan media online dalam penelitian ini untuk mengetahui perilaku pencarian informasi pertanian oleh petani jahe. Menurut Daft \& Lngel (dalam Yusup dan Subekti, 2010: 352) mutu suatu media komunikasi tergantung dari medianya dalam memproses ambigous communication, dan mengatakan bahwa media dengan mutu yang tinggi akan lebih efektif untuk equivocal taks dan leaner media lebih baik untuk unequivocal tasks.

Semakin majunya teknologi komunikasi dan informasi, semakin memudahkan khalayak untuk berinteraksi. Seperti halnya Internet yang saat ini menjadi bagian dari aktivitas masyarakat di berbagai kalangan. Fenomena yang sedang menjadi perbincangan adalah media online di Internet, seperti halnya google, yahoo, facebook, twitter, dan lain-lain. Media online di Internet menjadi trend dan tidak dapat dipungkiri lagi manfaat yang diberikan oleh media online tersebut. Manfaat yang diberikan berupa kemudahan mengakses informasi dan isu-isu yang tengah berkembang. Media online di Internet banyak menawarkan berbagai fasilitas untuk mencari dan berbagi informasi dalam pola laku manusia terkait dengan keterlibatan informasi.

Berangkat dari penggunaan media online bagi para petani di kampung kampung di Desa Putri Dalem Kecamatan Jatitujuh, yang secara geografis berbeda di sebelah utara Kabupaten Majalengka dan tetangga desa yang berbatasan langsung dengan Kabupaten Indramayu. Desa Putri Dalem mempunyai lahan pertanian yang sebagian besar merupakan hamparan usaha tani dengan petani padi. Hal tersebut perlu pengembangan lebih lanjut, mengingat sebagian besar penduduknya bermata pencaharian di sektor pertanian. Petani mempunyai rencana membuka lapangan usaha di daerah perdesaan dimana lahan serta progresnya pun menjanjikan dalam upaya pemanfaatan lahan tidur atau tidak produktif. Terlebih ke depan areal pertanian akan semakin terkikis dengan dibangunnya bandara internasional Jawa Barat di Kecamatan Kertajati yang notabene merupakan tetangga Kecamatan Jatitujuh, tentu saja jangkauan pangsa pasarnya pun sangat terbuka, dan dapat menjadi ekspor ke berbagai negara bagi Kabupaten Majalengka (hasil wawancara ketua petani, H. Djuhari).

Terkait dengan realitas yang dikemukakan tersebut, di Kampung Kaputren desa Putri 
Dalem mencoba untuk mengembangkan inovasi baru pertanian jahe yaitu dengan adanya Profesi Kelompok Petani Jahe Putri Mandiri yang merupakan salah satu pengembang ekonomi daerah, juga kaya akan potensi berupa memanfaatkan lahan perkebunan. Salah satunya petani mengembangkan potensi ekonomi masyarakat perdesaan di bidang pertanian khususnya budidaya jahe gajah dalam menghadapi pembangunan pertanian untuk itu meningkatkan pertanian membentuk suatu kelompok tani jahe "Putri Mandiri" di Kampung Kaputren yang terletak di bagian selatan dari desa Putri Dalem.

Sebenarnya para petani juga mengundang pakar petani di Sukabumi untuk menangani penanaman jahe di Kampung Kaputren. Dengan demikian pengetahuan pakar petani atau pengalaman dirinya selalu menggunakan media online untuk mencari informasi pertanian. Dengan kegagalan panen oleh petani, maka pakar petani jahe menawarkan berupa pengajuan dari pakar petani berkisar harganya Rp 8.000/ polybag pada petani jahe putri mandiri dengan tanaman jahe sistem polybag yang diperoleh dari media online.

Pakar petani jahe merupakan sumber informasi untuk menyebarkan pengetahuan kepada petani melalui media online. Berupa media online yang digunakan google, yahoo, facebook, dan twitter untuk penyebaran informasi pertanian pada petani jahe tersebut. Dengan penggunaan media online tersebut para petani jahe sangat terbantu dalam pencarian informasi pertanian melalui media online. Untuk mendapatkan informasi pertanian penanaman dan penanggulangan dengan sistem polybag mempunyai kendala pada tanaman jahe banyak hambatan di musim kemarau perkepanjangan, iklim tropis, dan dataran rendah. Maka dari itu, tanaman jahe ini biasanya tumbuh di dataran tinggi seperti yang ada di daerah pegunungan. Begitu juga kendala tanaman jahe di daerah kampung Kaputren tersebut tumbuh dengan baik karena menggunakan pola pencarian informasi di media online yang digunakan oleh pakar petani untuk mencari informasi pertanian tentang cara penanggulangan pada musim kemarau berkepanjangan, iklim, tropis, dan dataran rendah.

Petani selalu membutuhkan pencarian lebih lanjut melalui media online untuk menambah pengetahuan cara-cara penanggulangannya dengan membuat jejaring komunikasi antar petani melalui media sosial. Perilaku pencarian informasi melalui media online pada Kelompok Petani Jahe Putri Mandiri untuk menambah pengetahuan dari sumber-sumber informasi pertanian.

Sedangkan seorang petani melakukan sharing atau berbagi informasi pertanian antarpetani untuk menambah wawasan dan pengembangan tanaman jahe gajah melalui media online secara penyebaran informasi sangat baik bagi petani. Kebutuhan perilaku petani melakukan perilaku pencarian informasi pertanian pada kelompok tani jahe putri mandiri sangat terbantu dengan adanya media online merupakan alat bantu supaya mudah dan cepat menemukan informasi tentang harga jahe gajah di pasaran.

Melalui media online (Facebook dan twitter) informasi yang dibutuhkan akan mudah diperoleh pertanian modern. Didalam perkembangan teknologi komunikasi memberikan petani berkesempatan untuk memperoleh informasi teknis dan ekonomis dengan cepat atau menggunakannya secara efektif dan efisien untuk pengambilan keputusan menggunakan media online.

Berdasarkan uraian di atas penelitian ini di bidang pertanian yang berupa Perilaku Pencarian Informasi Pertanian Melalui Media Online Pada Petani Jahe adalah untuk memperbaiki atau memecahkan masalah yang ada dalam bidang pertanian. Sedangkan petani akan menggunakan sumber-sumber informasi pertanian yang ada di media online.

Melihat kompleksitas masalah yang dihadapi berdasarkan fokus penelitian tersebut, maka penulis berusaha mengidentifikasi masalah dalam beberapa pertanyaan penelitian. Hal ini penting agar lebih terarah pada inti permasalahan yang akan diteliti. Adapun pertanyaan dalam penelitian ini yaitu: (1) mengapa petanijahe putrimandiri membutuhkan informasi pertanian melalui media online? (2) bagaimana para petani jahe putri mandiri membutuhkan informasi pertanian melalui media online? (3) bagaimana pola komunikasi yang dilakukan petani jahe putri mandiri dalam mengimplementasikan pencarian informasi pertanian? (4) mengapa informasi pertanian melalui media online berperan penting dalam menanggulangi permasalahaan pertanian jahe? (5) bagaimana para petani menggunakan media 
online sebagai cara untuk menanggulangi permasalahaan pertanian jahe?.

Kegunaan teoretis dari penelitian ini diharapkan merupakan tambahan sumber informasi yang khas bagi ilmuwan dan peneliti yang berorientasi di kelompok petani jahe putri mandiri, terutama subjek penelitiannya perilaku pencarian informasi pertanian melalui media online dan merupakan sarana kontribusi bagi peneliti terhadap berkembangnya ilmu komunikasi dan informasi sesuai bidang yang selama ini ditekuni, sehingga diharapkan penelitian ini nantinya bisa memperkaya ilmunya melalui media online dan informasi bagi petani.

Hasilpenelitianinidiharapkanbisadijadikan salah satu landasan dalam pengembangan penanaman jahe dalam upayanya mengatasi media penanaman secara sistem polybag pada musim kemarau berkepanjangan oleh kelompok tani jahe putri mandiri, dan sebagai sarana untuk mengembangkan wawasan bagi petani tentang pemecahan masalah pada kelompok tani jahe putri mandiri pada iklim panas khususnya yang terkait dengan aspek keterlibatan dan ketergunaan informasi pada setiap penanaman jahe gajah pada musim kemarau.

\section{METODE PENELITIAN}

Penelitian ini menggunakan metode kualitatif dengan pendekatan studi kasus dikarenakan peneliti melakukan konstruksi realitas di lapangan mengenai pencarian informasi melalui media online sebagai sumber informasi petani jahe putri mandiri. Dalam hal ini penulis menelaah data yang sebanyak mungkin dari subjek penelitian yang tidak lain adalah pakar petani, petani jahe dan ketua kelompok tani jahe putri mandiri. Pada penelitian ini juga penulis mempelajari semaksimal mungkin subjek penelitian yang bertujuan untuk memberikan pandangan yang lengkap dan mendalam mengenai subjek penelitian.

Menurut Mulyana (dalam Hidayat 2012: 140) studi kasus ialah uraian dan penjelasan komprehensif mengenai berbagai aspek seorang individu, suatu kelompok sosial, suatu organisasi (komunitas), suatu program atau situasi sosial. Peneliti studi kasus berupaya menelaah sebanyak mungkin data mengenai subjek yang diteliti. Begitu juga menurut
Creswell (dalam Yin, 2013: 14), case studies are a design of inquiry found in many fields, especially evaluation, in which the researcher develops an in-depth analysis of a case, often a program, event, activity, process, or one or more individuals.... Pendapat tersebut menjelaskan bahwa studi kasus merupakan sebuah desain penelitian yang dapat diterapkan dalam bidang yang berhubungan dengan evaluasi, pengembangan dalam sebuah kasus, program, acara, kegiatan, dan individu.

Selain itu, studi kasus juga mencoba untuk menggali keunikan dari suatu kasus atau multikasus secara holistik dan komprehensif (Hidayat, dkk, 2017: 94). Kelompok Petani Jahe Putri Mandiri dikenal sebagai pertanian jahe gajah di Kampung Kaputren Desa Putri Dalem Kecamatan Jatitujuh. Objek dari penelitian ini memiliki keunikan tersendiri yang tidak dimiliki oleh petani jahe lainnya yang ada di wilayah Majalengka, yaitu petani jahe putri mandiri selalu berkomunikasi antarpetani jahe lainnya dengan cara mencari informasi pertanian melalui media online, di antaranya google, yahoo, facebook, dan twitter.

\section{HASIL DAN PEMBAHASAN}

Kebutuhan informasi merupakan suatu keadaan yang terjadi dalam struktur kognisi seseorang yang dirasakan ada kekosongan informasi sebagai akibat yang dikerjakan atau untuk memenuhi rasa ingin tahu. Kekurangan tersebut perlu dipenuhi dengan informasi baru yang sesuai dengan kebutuhannya, kebutuhan informasi dipengaruhi oleh faktor yang bersifat internal maupun eksternal. Faktor eksternal misalnya tanaman jahe yang bermasalah harus ditanggulangi dengan cepat, sedangkan faktor internal misalnya adanya rasa ingin tahu. Rasa ingin tahu inilah yang mendorong seseorang untuk memenuhi kepuasan rasa ingin tahunya yang diwujudkan dalam bentuk kebutuhan. Faktor eksternal dapat bersifat kondisional, artinya latar belakang lingkungan dan pengalaman berpengaruh terhadap kebutuhan informasi.

Kebutuhan informasi petani Jahe Putri Mandiri menjadikan media online sebagai pemenuhan kebutuhan informasi dalam Pencarian Informasi Pertanian dan penanggulangan penanaman jahe dengan sistem polybag. Penggunaan media online 
tersebut juga didasari dengan pengetahuan yang dimiliki, karena dalam pemanfaatan dan penggunaan media online memiliki cara dan teknik yang berbeda dengan sumber informasi lainnya baik tercetak maupun digital.

Sumber informasi yang digunakan oleh petani jahe berupa pangkalan data (Internet) dalam melakukan pencarian sumber informasi yang berasal dari media online juga diakses oleh pakar petani dan petani jahe putri mandiri, karena dianggap sumber informasi yang paling lengkap. Menurut informan memulai bisnis budidaya jahe awalnya dengan cara di gelar, sistem ini sudah dilakukan dan tidak berhasil, maka dari itu petani membutuhkan informasi tepat tentang penanaman jahe melalui media online.

Keterbatasan penyuluh di kabupaten Majalengka membuat petani jahe di kampung Kaputren mengambil langkah untuk mencari informasi dan mengembangkan pengetahuannya akan pemahaman tentang pertanian melalui media online. Petani membutuhkan informasi pertanian dimana sebagian besar mencakup perkembangan budidaya tanaman jahe gajah dengan sistem polybag yang didapat melalui media online. Sistem tersebut sangat berperan dalam pembangunan pertanian yang ada di kelompok Petani Jahe Putri Mandiri.

Informasi yang dibutuhkan petani berbeda untuk setiap kategori petani atau kelompok, misalnya kategori petani berdasarkan luas penguasaan lahan atau wilayah. Selain itu membutuhkan berbagai jenis informasi dan sumber informasi, petani memiliki perilaku pencarian informasi yang berbeda. Faktorfaktor seperti literasi informasi, ketersediaan informasi, dan kemudahan akses terhadap informasi akan memengaruhi kebutuhan, perilaku pencarian, akses, dan pemanfaatan informasi dapat dikatakan penelitian dapat dipertanggungjawabkan. Sedangkan menggunakan media online yang dapat diakses kapanpun dan dimanapun dirasakan petani jahe selalu membutuhkan informasi pertanian dan manfaatnnya begitu baik bagi para petani. Dengan keadaan seperti ini lebih membantu ketika mengakses google, yahoo, facebook dan twitter yang tidak memerlukan waktu lama dalam pencarian informasi pertanian terhadap perilaku petani jahe putri mandiri.

Faktor kemajuan teknologi dalam masyarakat modern sangat dipengaruhi oleh lingkungan, interaksi antar perorangan maupun antar kelompok menjadi faktor penting untuk menentukan keberhasilan penyampaian informasi dalam komunikasi. Komunikasi yang saling berhubungan dan saling mempengaruhi antara komunikator dan komunikan untuk mencapai tujuan bersama akan membentuk jaringan komunikasi.

Bahwa informasi dipengaruhi oleh kebutuhan pribadi yang berkaitan dengan kebutuhan fisiologis, afektif, maupun kognitif. Pada kebutuhan ini juga memiliki kaitan terhadap peran seseorang dalam pekerjaan atau kegiatannya, dan dengan tingkat kompetensi seseorang sebagaimana diharapkan oleh lingkungannya. Saat seseorang terdorong untuk mencari informasi, semua faktor di atas akan menentukan bagaimana sesungguhnnya ia berperilaku mencari informasi. Selain itu, faktor rintangan juga termasuk kedalamnya sehingga hal itu juga menentukan bagaimana ia berperilaku terhadap sistem tersebut, yang dalam penelitian ini adalah media online.

Pemakaian media online dengan fasilitas warung Internet berada di kampung Kaputren sangat membantu sekali pada petani. Begitupun juga petani membutuhkan informasi pertanian Jahe Gajah yang mempunyai peranan penting dalam pertanian Indonesia. Hingga saat ini dapat menunjukkan hasil yang maksimal jika dilihat dari tingkat kesejahteraan petani dalam pembangunan perekonomian wilayah Kabupaten Majalengka.

Faktor kemajuan teknologi dalam masyarakat modern sangat dipengaruhi oleh lingkungan, interaksi antar perorangan maupun antar kelompok menjadi faktor penting untuk menentukan keberhasilan penyampaian informasi dalam komunikasi. Komunikasi yang saling berhubungan dan saling mempengaruhi antara komunikator dan komunikan untuk mencapai tujuan bersama akan membentuk jaringan komunikasi.

Semakin majunya teknologi komunikasi dan informasi, semakin memudahkan khalayak untuk berinteraksi. Seperti halnya Internet yang saat ini menjadi bagian dari aktivitas masyarakat di berbagai kalangan. Lingkungan perannya terhadap perilaku petani untuk mencari informasi awalnya sebelum mengenal media Internet, petani dalam mencari informasi cukup banyak membutuhkan biaya dan waktu yang cukup lama, terutama dalam kegiatan 
penemuan dan pencarian informasi pertanian yang dibutuhkan yang semuanya masih mengandalkan media kertas, dan mereka masih harus mencari di sebuah katalog dan media lainnya.

Pada penelitian ini, para petani mengenal media online dari lingkungan, terutama pakar petani yang berbarengan semasa becocok tanam. Akan tetapi memang ada petani mengetahui media online dari kita dapat melihat bahwa lingkungan berpengaruh besar terhadap seseorang untuk menggunakan sebuah media untuk pengetahuan. Seringkali informasi yang diharapkan petani menemukan penjelasan secara teoritis tanpa mengkaji lebih dalam, baik dalam sebuah penelitian ataupun temuan lainnya. Dari sinilah ketidakpuasan informasi yang dirasakan oleh petani.

Masyarakat di lingkungan sekitarnya terhadap perilaku petani mengenai pencarian informasi melalui media online cukup berpengaruh dalam pembangunan pertanian saat ini, lebih ditekankan pada peningkatan kualitas sumber daya manusia. Sedangkan para petani untuk itu menggunakan media online dapat menafsirkan situasi yang sedang berkembang, sehingga petani jahe dapat membuat perkiraan ke depan dan meminimalisir kemungkinan masalah yang akan dihadapi. Keputusan kelompok tani jahe salah satu dari jenis keberhasilan penyebaran informasi tidak terlepas pada masyarakat di sekitarnya. Suatu teknologi komunikasi tidak terlepas dari peran media online yang menjalankan fungsinya sebagai agen pembaharu tetapi berani saling berkomunikasi pada komunitas pertanian di Indonesia.

Kutipan di atas lebih kurang memiliki arti pada model tersebut terdapat tiga faktor yang dianggap penting untuk menjelaskan fenomena kebiasaan menemukan informasi (information seeking), yaitu konteks kehidupan pencari informasi, sistem informasi yang digunakannya, dan sumberdaya informasi yang mengandung berbagai informasi yang diperlukan. Berdasarkan hal tersebut dapat diketahui bahwa kehidupan pencarian informasi yang dialami seseorang dipengaruhi beberapa aspek yang ada disekitarnya, dan aspek itulah yang dinamakan "semesta pengetahuan" (Wilson, 2000).

Berikut akan digambarkan sebuah model berdasarkan temuan dalam penelitian ini, yang mana terdiri dari pakar petani, kebutuhan informasi, lingkungan Kelompok Petani Jahe Putri Mandiri, dan perilaku petani pada model tersebut. Keempat aspek tersebut saling

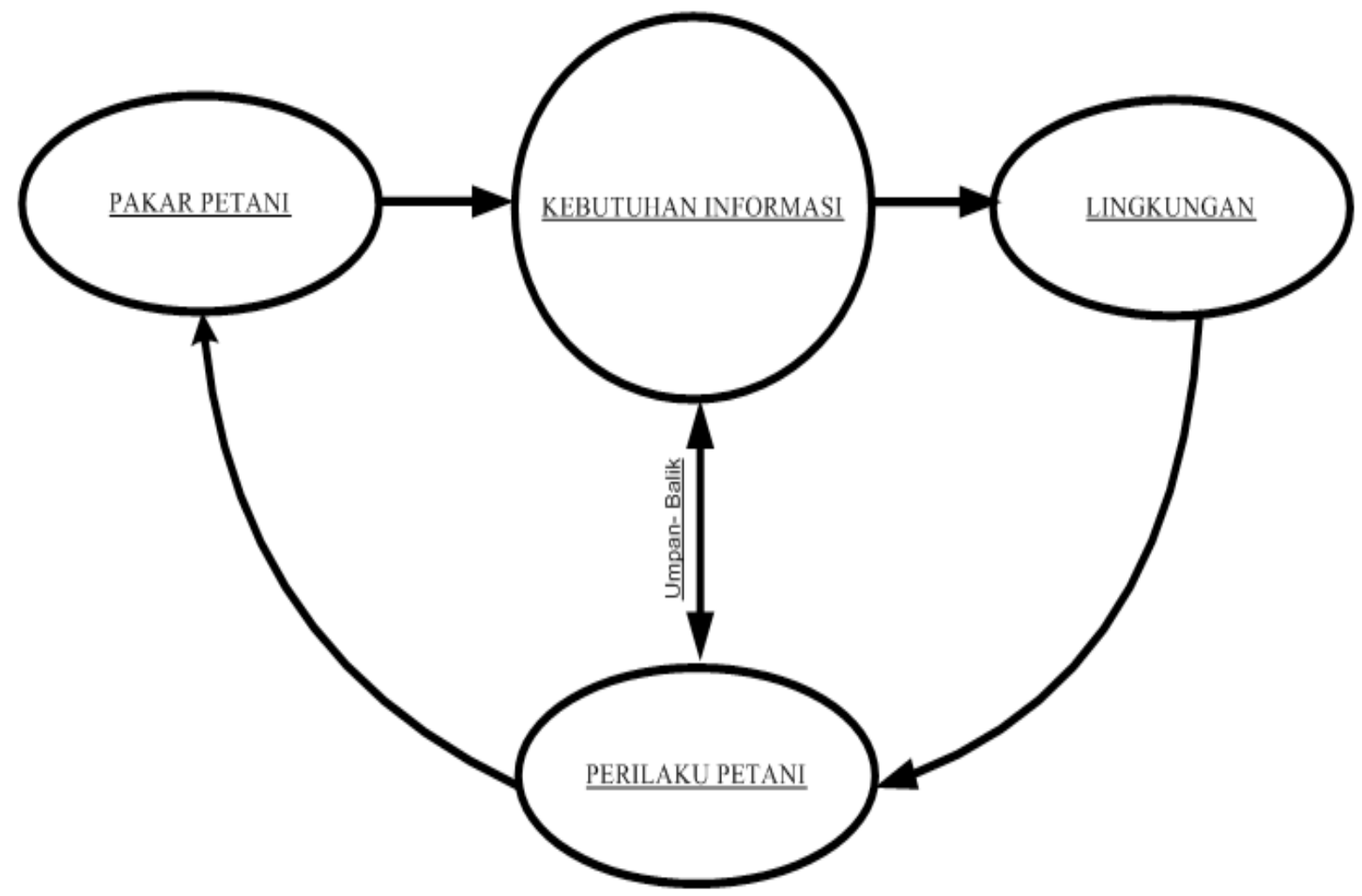

Sumber: Hasil Penelitian Penulis, 2016

Gambar 1 Model Kebutuhan Informasi Melalui Media Online 
Pola pencarian informasi dapat diartikan sebagai suatu gambaran kebiasaan seseorang atau langkah-langkah seseorang dalam mencari informasi. Pola ini dapat berupa tahapan pencarian dengan ciri-ciri untuk masingmasing tahap, atau ciri berdasarkan karakteristik kelompok, serta berdasarkan keuletan dalam pencarian informasi. kemudian secara intensif dilakukan oleh para petani, Bagaimana suatu proses komunikasi pertanian bekerja dan suatu keputusan untuk melakukan inovasi bagi petani untuk dilakukan. Juga telah di jelaskan oleh pakar petani secara sepintas bagaimana petani akan mengambil suatu keputusan dalam pencarian informasi pertanian melalui media online.

Pada tahap pertama, dilakukan Perencanaan merupakan tahapan awal sebelum memulai mencari informasi. Dengan adanya perencanaan, suatu kegiatan petani akan berjalan sesuai dan tidak melenceng dari sasaran. Begitu juga dalam hal mencari informasi pertanian jahe gajah melalui media online, tahapan-tahapan harus di mulai supaya pencarian informasi berjalan sesuai yang direncanakan.

Terdapat beberapa perbedaan penting antara prinsip kerja mesin dengan manusia yang harus dipahami terlebih dahulu untuk dapat mengetahui perilaku responden ketika melakukan pencarian. Pemahaman mengenai internet terutama sarana web, sebagai setting dari penelitian ini juga sama pentingnya. Pencarian sebagai suatu aksi yang disadari didahului dengan kegiatan identifikasi kebutuhan informasi kemudian ketika sudah diputuskan bahwa pencarian akan dilakukan di web maka perencanaan mengenai sumber informasi dari search engine apa yang digunakan sudah dipikirkan.

Berkaitan waktu pada petani mencari informasi pencarian informasi, hasil waktu pencarian informasi yang di maksud adalah waktu pencarian informasi selama berada di tempat. Pencarian informasi ini dilakukan ketika ada masalah informasi tersebut di lakukan tergantung kapan tanaman jahe di serang hama. Itulah waktu pencarian merupakan tahapan awal sebelum memulai mencari informasi. Dengan adanya waktu, suatu kegiatan petani akan berjalan sesuai rencana dan sasaran.

Proses inovasi para petani ini menggambarkan suatu pola komunikasi dalam pencarian informasi pertanian tersebut. Terdapat beberapa komponen yang diperlukan pola pencarian informasi pertanian di lingkungan kelompok tani jahe Putri Mandiri di Kampung Kaputren Desa Putri Dalem Kecamatan Jatitujuh Kabupaten Majalengka. Hal tersebut digambarkan pada gambar 2, model pola komunikasi yang dibicarakan oleh pakar petani dan kelompok petani jahe Putri Mandiri yaitu perencanaan pencarian informasi, waktu pencarian informasi, metode pencarian, sumber informasi, prosedur pencarian informasi dan tahapan pencarian. Keenam aspek tersebut saling memiliki kaitan.

Peranan pengembangan informasi di media online sangat berpengaruh untuk menghasilkan efek-efek yang sinergis dalam menumbuhkan pertanian. Misalnya untuk membantu para petani jahe yang mengolah lahannya dengan cara-cara pertanian modern dalam saat ini untuk memecahkan masalah tanaman Jahe Gajah menggunakan sistem polybag, dengan tanahnya dataran rendah dan cuaca kemarau yang berkepanjangan.

Seiring dengan peningkatan kualitas sumber daya petani jahe Putri Mandiri pun menggunakan media online lebih mudah untuk mencari informasi pertanian sebagai cara menanggulangi permasalahan budidaya Jahe Gajah tumbuh dengan baik menggunakan sistem polybag. Hal ini menjadikan petani menambah pengetahun pertanian khusunya penanggulangan budidaya Jahe Gajah dengan cuacana kemarau berkepanjangan dan tanahnya dataran rendah lebih efektif dan efesien. Adanya perubahan perilaku petani tentang pencarian informasi yang diterapkan sangat mudah dan cepat dipahami dengan hasilnya menguntungkan bagi petani Jahe Putri Mandiri.

Petani menggunakan sumber-sumber dari media online untuk mendapatkan informasi yang diperlukan dalam mengelola usahataninya. Gagasan tersebut yang melandasi konsep sistem pengetahuan peningkatan keserasian antar pengetahuan, lingkungan, dan teknologi yang diperlukan melalui sinergi dari berbagai perilaku yang akan menciptakan proses kesinambungan dalam pencarian informasi (search), serta pemanfaatan bersama (sharing) inovasi. Di dalam perkembangan teknologi komunikasi memberikan petani kesempatan untuk memperoleh informasi teknis dan ekonomis dengan cepat ataupun menggunakannya secara efektif dan efesien untuk pengambilan 
Sumber: Hasil Penelitian Penulis, 2016

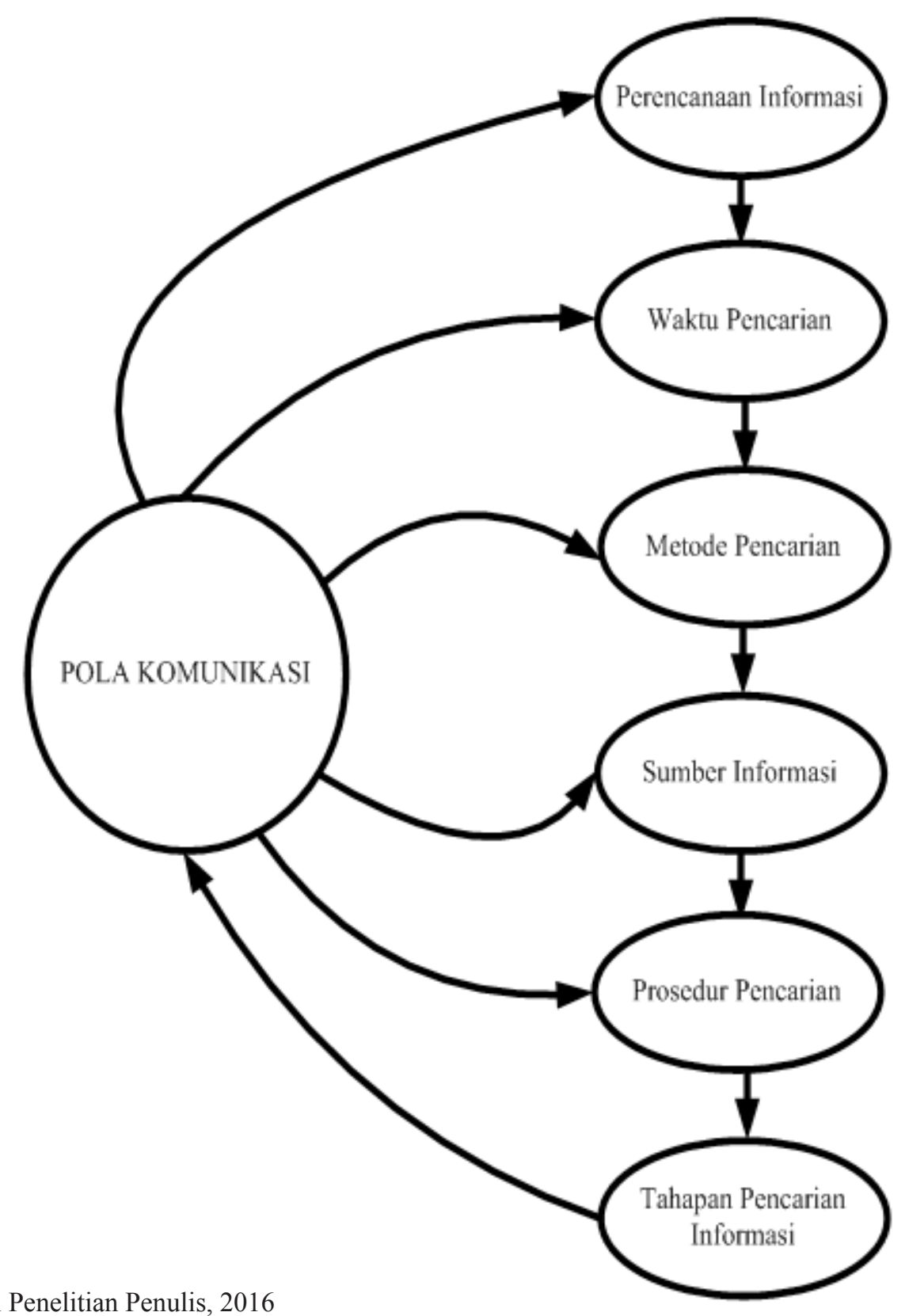

Gambar 2 Model Komunikasi Umpan-Balik Langsung Dari Pola Komunikasi Petani Jahe

keputusan menggunakan media online. Dalam kemudahan akses informasi teknologi pertanian dari sumber informasi yang digunakan juga merupakan faktor tingginya pemanfaatan sumber informasi dari sesama petani dan pakar petani.

Pencarian informasi merupakan keseluruhan pola laku manusia terkait dengan keterlibatan informasi. Sepanjang laku manusia memerlukan, memikirkan, memperlakukan, mencari, dan memanfaatkan informasi dari beragam saluran, sumber, dan media penyimpanan informasi lain, itujuga termasuk ke dalam pengertian perilaku informasi. Umniyati, dkk (2017: 114) menjelaskan pula bahwa media baru adalah bentuk komunikasi secara interaktif yang melibatkan penggunaan teknologi dan modalitas media di era teknologi digital seperti halnya Internet sehingga memungkinkan untuk menciptakan, memodifikasi dan menyebarkan isi pesan dengan menggunakan sarana yang mudah, gratis dan tidak mahal.

Berdasarkan paparan di atas dengan temuan di lingkungan pada kelompok tani jahe Putri Mandiri di kampung Kaputren Desa Putri Dalem Kecamatan Jatitujuh Kabupaten Majalengka akan digambarkan sebuah model peranan informasi pakar petani dan kelompok petani jahe putri mandiri yaitu informasi dan media online. Pada model tersebut kedua aspek tersebut saling memiliki kaitan, yaitu penjelasannya pada gambar 3 . 


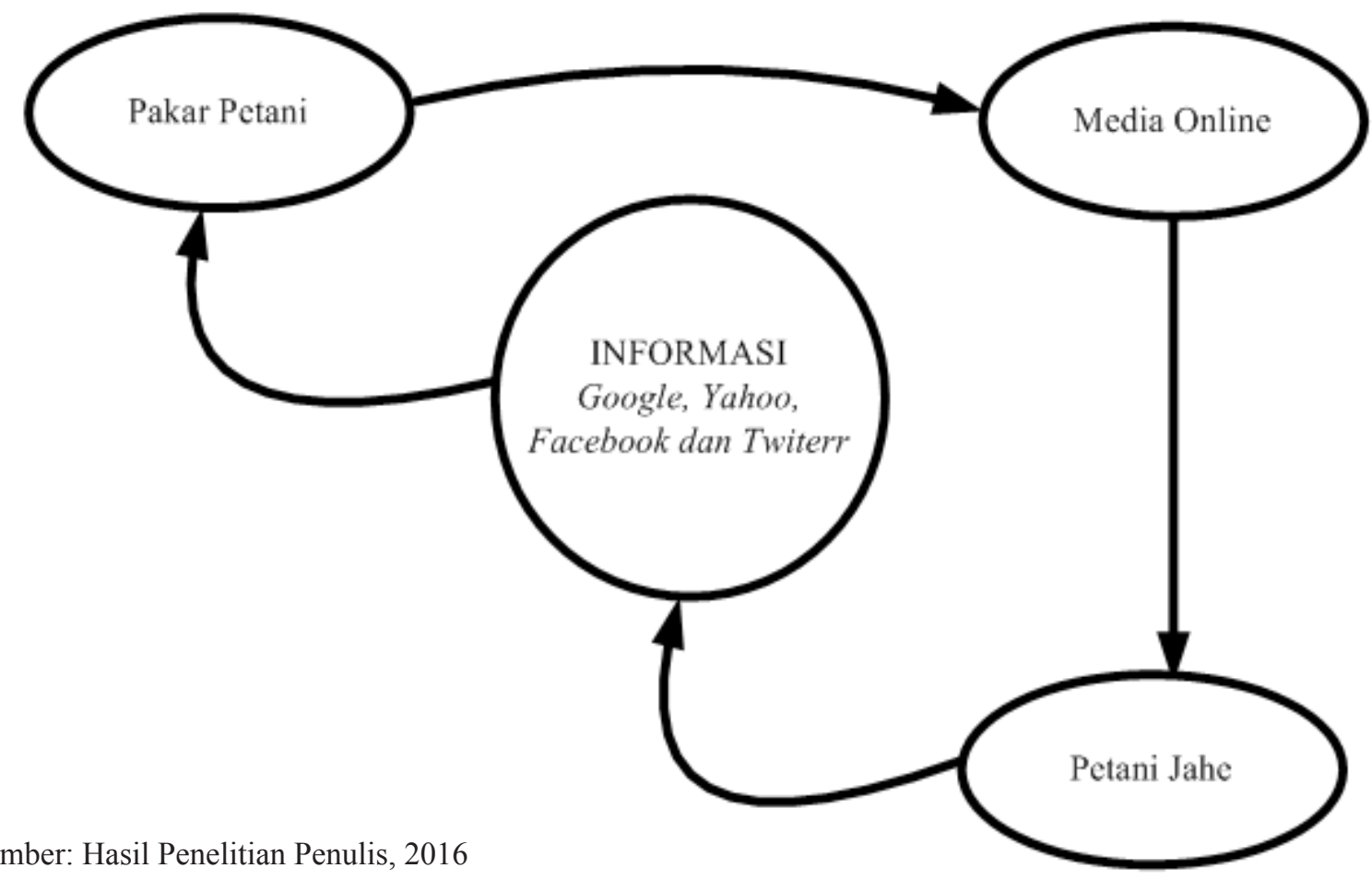

Gambar 3 Model Peranan Informasi

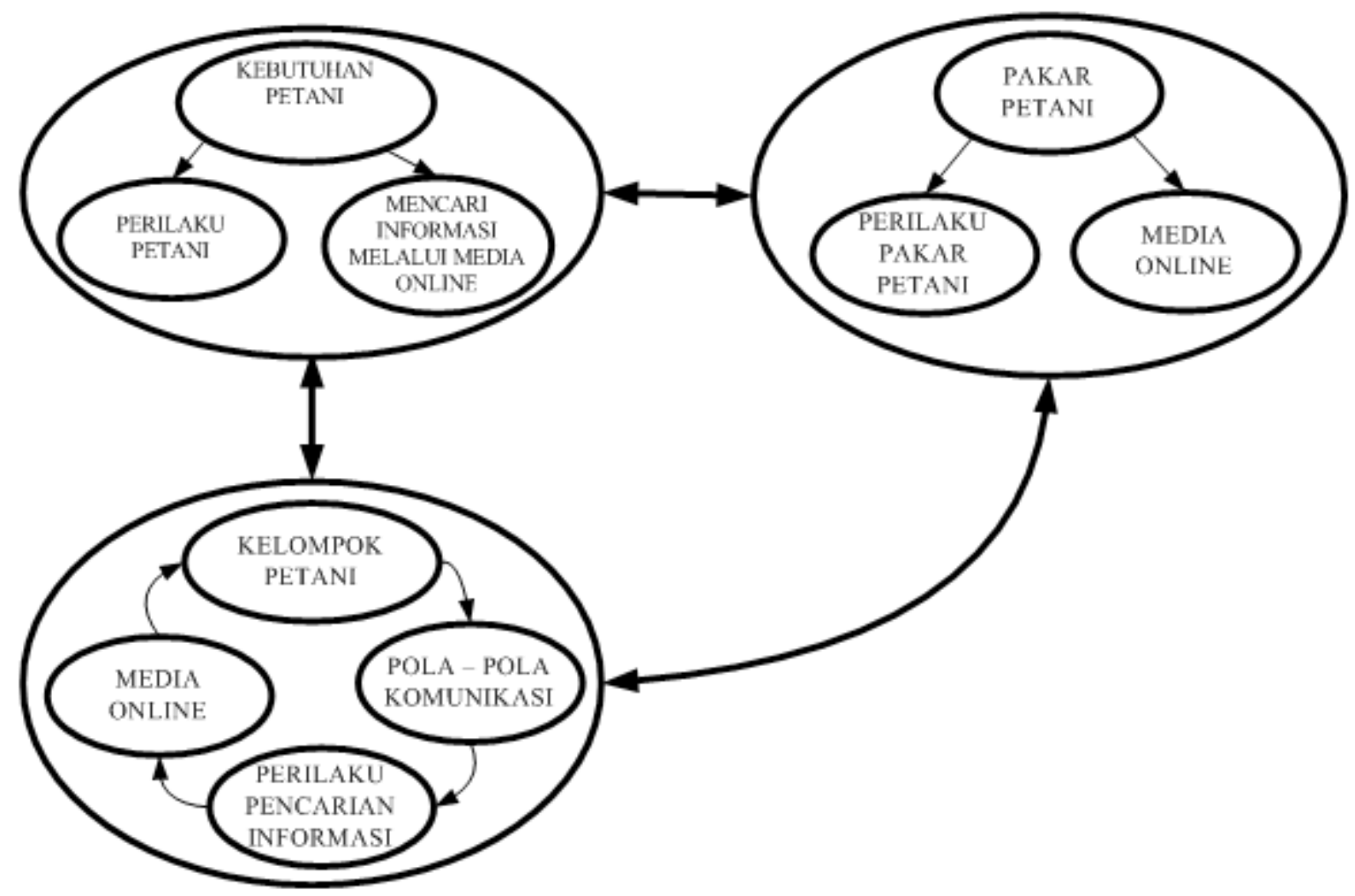

Sumber: Hasil Penelitian Penulis, 2016

Gambar 4 Model Komunikasi Pertanian

Dalam pembahasan penelitian ini, diperoleh gambaran model komunikasi pertanian berdasarkan temuan di lapangan. Terdiri dari Kebutuhan Petani, Pakar Petani, dan Kelompok Petani. Pada model tersebut terdapat tiga aspek yang saling berkaitan, penjelasannya dapat dilihat pada gambar 4 .

Kebutuhan informasi merupakan suatu keadaan yang terjadi dalam struktur kognisi seseorang yang dirasakan ada kekosongan informasi sebagai akibat yang dikerjakan atau untuk memenuhi rasa ingin tahu. Sesuai 
dengan pendapat yang diungkapkan oleh TD Wilson (2000) yang terdiri dari users life world, information system, dan information resources juga berperan di dalam model ini, karena seseorang mencari dan menggunakan informasi sesuai dengan kehidupan, sistem informasi dan sumber informasi. Kelompok petani kemudian mendapatkan informasi pertanian sesuai dengan kebutuhan informasi petani jahe tersebut.

Petani jahe merupakan pengguna sumber informasi untuk pengetahuan kepada petani jahe putri mandiri melalui media online. Media online yang digunakan oleh petani yaitu google dan facebook untuk penanggulangan pertanian jahe gajah di musim kemarau berkepanjangan. Penelitian ini perilaku petani untuk melakukan pencarian informasi pertanian melalui media online. Dengan penggunaan media online tersebut petani jahe putri mandiri sangat terbantu dalam pencarian informasi pertanian melalui media online. Untuk mendapatkan informasi pertanian penanaman dan penanggulangan dengan sistem polybag.

Dengan penggunaan media online tersebut pakarpetanijahe sangat terbantu dalampencarian informasi pertanian melalui media online. Untuk mendapatkan informasi pertanian penanaman dan penanggulangan dengan sistem polybag mempunyai kendala pada tanaman jahe banyak hambatan di musim kemarau perkepanjangan, iklim tropis, dan dataran rendah. Maka dari itu, tanaman jahe ini biasanya tumbuh di dataran tinggi seperti yang ada di daerah pegunungan. Begitu juga kendala tanaman jahe di daerah kampung Kaputren tersebut tumbuh dengan baik dikarenakan menggunakan pola pencarian informasi di media online yang digunakan oleh pakar petani untuk mencari informasi pertanian tentang cara penanggulangan pada musim kemarau berkepanjangan, iklim, tropis, dan dataran rendah.

Pakar petani jahe merupakan sumber informasi untuk menyebarkan pengetahuan kepada petani melalui media online. Berupa media online yang digunakan google, yahoo, facebook, dan twitter untuk penyebaran informasi pertanian pada petani jahe tersebut. Dalam penelitian ini perilaku pakar petani untuk melakukan pencarian informasi sesuai dengan pendapat TD Wilson (2000) yang merupakan sebuah model sebagai guidance pada penelitian ini, yang terdiri dari psysiological needs, affective needs, dan cognitive needs.
Pada poin lingkungan yang dimaksud yaitu lingkungan Kelompok Petani Jahe Putri Mandiri Kampung Kaputren yang mana membutuhkan informasi untuk memenuhi kebutuhannya dalam penyelesaian penanggulangan tanaman jahe dan kebutuhan lainnya. Lingkungan disini kelompok petani jahe Putri Mandiri yang saling berinteraksi sebagai makhluk sosial, dimulai dari mencari informasi, bergaul dan lain-lain. Ketika petani memiliki kebiasaan penanggulangan tanaman menggunakan media online, maka teman petani atau koleganya di dalam lingkungan tersebut tentu akan ikut untuk menggunakan media online. Sebagaimana diri orang kedua tercipta akan lingkungan yang ada di sekitar berita. Sejalan dengan pendapat Koswara dan Mulyana (2016: 200) bahwa dalam komunikasi kelompok keberhasilan pertukaran informasi antara mentor dan target audiens merupakan aspek yang mendapat perhatian utama.

Ketika pakar petani telah melewati fase lingkungan yang mana menjadi tempat untuk berinteraksi dan berdiskusi, maka akan terciptalah sebuah pola komunikasi antar petani jahe dan petani jahe Indonesia. Pada penelitian disini pola komunikasi yang dimaksud yaitu pengetahuan dalam mengakses, menelusur dan bertukar informasi mengenai pertanian jahe gajah melalui media online. Adanya pertukaran informasi sehingga membentuk sebuah pengetahuan di dalam diri seseorang.

Informasi yang didapat dari media online dari para petani dalam sebuah aktivitas atau keahlian tertentu tentulah berbeda-beda. Hal ini sesuai dengan pengetahuan, pengalaman dan ilmu yang dimiliki. Ketika seseorang memiliki pengetahuan kemudian akan terbentuklah sebuah kemampuannya. Sejalan dengan hal tersebut, Nurtyasrini dan Hafiar (2016: 221) mengemukakan bahwa pengalaman merupakan suatu proses pembelajaran dan pertambahan perkembangan potensi bertingkah laku baik dari pendidikan formal maupun nonformal atau bias diartikan sebagai suatu proses yang membawa seseorang kepada suatu pola tingkah laku yang lebih tinggi. Pada penelitian ini, ketika pakar petani memiliki pengetahuan mengakses, dan menelusur maka akan terbentuklah kemampuannya untuk pencarian informasi.

Berangkat dari penggunaan media online yang didapat oleh pakar petani bagi para petani di Kampung Kampung di Desa Putri 
Dalem Kecamatan Jatitujuh, penelitian ini mengungkapkan perilaku pencarian informasi pertanian pada jaman sekarang memang sudah tidak sulit karena sudah hadir tersedianya di media online ataupun konvensional yang berguna untuk menunjang dan memenuhi kebutuhan informasi bagi para petani jahe putri mandiri yang membutuhkan informasi pertanian. Dalam penelitian ini perilaku pencarian informasi sesuai dengan pendapat TD Wilson (2000) yang merupakan sebuah model sebagai guidance pada penelitian ini, yang terdiri dari psysiological needs, affective needs, dan cognitive needs. Pada tiga poin tersebut menjadi perilaku pencarian informasi oleh kelompok petani jahe putri mandiri dalam mencari informasi pertanian melalui media online untuk memenuhi kebutuhan informasinya.

\section{SIMPULAN}

Penelitian ini berusaha untuk mengkaji bagaimana petani Jahe Putri Mandiri dan para pakar petani jahe menggunakan media online sebagai sumber informasi di dalam perilaku pencarian informasi pertanian. Adapun hasil simpulan dari penelitian ini, yaitu sebagai berikut: (1) mereka merasa belum cukup mendapatkan penyuluhan dalam pengetahuan pertanian. Sehingga ketua kelompok perlu untuk memperbaiki pola bercocok tanam jahe melalui media online, (2) petani mendapatkan informasi pertanian yang dibutuhkan melalui media online yaitu google, yahoo, facebook, dan twitter dan selanjutnya mendapatkan bantuan dari pakar pertanian di bidang jahe gajah, (3) pola komunikasi yang dilakukan oleh petani dan ketua kelompok petani setiap hari selalu menggunakan media online, (4) penggunaan Media online terhadap petani sangat cocok untuk diimplementasikan tentang tanaman jahe gajah pada Desa Putri Dalem Kecamatan Jatitujuh Kabupaten Majalengka, dan (5) informasi yang diperoleh petani melalui media online. Selanjutnya petani mendiskusikan dengan kelompok petani jahe di Indonesia melalui media online, setelah itu mereka mendiskusikannya lagi dalam kelompok tani jahe putri mandiri terutama yang berkaitan dengan cara-cara penanggulangan permasalah jahe gajah.

Adapun saran yang peneliti berikan berdasarkan hasil penelitian yang diperoleh, antara lain: (1) para petani jahe sebaiknya tidak hanya berdiskusi dan mencari informasi melalui media online, tetapi berdiskusi dan berkomunikasi dengan pakar petani, (2) memberikan informasi mengenai media online tidak hanya dilakukan satu atau dua kali, sebaiknya dilakukan terus menerus secara kontinyu, dapat dilakukan melalui email, media sosial (grup diskusi) dan bahkan kegiatan rapat dan acara yang biasa dilakukan oleh kelompok petani jahe putri mandiri dalam waktu berkala, dan (3) sebaiknya setiap petani harus memiliki laptop dan handphone untuk mengakses media online sebagai media 'referensi' dan bahan bacaan dalam perkembangan pertanian modern.

\section{DAFTAR PUSTAKA}

Djoyohadikusumo, S. (1994). Perkembangan pemikiran ekonomi indonesia. Pustaka LP3ES.

Mulyana, D, (2002). Metodologi penelitian kualitatif: paradigma baru ilmu komunikasi dan ilmu sosial lainnya. Cetakan kedua. Remaja Rosdakarya, Bandung.

Hidayat, D. R. (2014). Fenomena iklan baris kesehatan di surat kabar lokal. Diakses dari http://journal.unpad.ac.id/jkk/ article/view/7380/3383. Jurnal Kajian Komunikasi. Volume 2, No. 2, Desember 2014, hlm 138-147.

Hidayat, D., Kuswarno, E., Zubair, F., dan Hafiar, H. (2017). Message platform atribut siger lampung di dalam kebhinekaan multikultur. Diakses dari http://journal. unpad.ac.id/jkk/article/view/9481/5724. Jurnal Kajian Komunikasi Volume 5, No. 1, Juni 2017 hlm 91-101.

KIM Provinsi Lampung. (2014). Pemanfaatan teknologi informasi dan komunikasi untuk pemberdayaan petani dan nelayan. Diakses dari http://kimprovinsilampung.blogspot. co.id/2013/05/pemanfaatan-teknologiinformasi-dan.html 30 september 2016 pukul 13.00.

Koswara, I. \& Mulyana, S. (2016). Implementasi model komunikasi kelompok fasilitator dalam pelaksanaan program rutilahu di kota cimahi. Diakses dari http://journal. unpad.ac.id/jkk/article/view/7814/5327. Jurnal Kajian Komunikasi Volume 4, No. 2, Desember 2016, hlm 199 - 206. 
Levis, L. R. \& Henuk, Y. L. (2005). Komunikasi Pertanian. Lembaga Penelitian Universitas Nusa Cendana, Kupang.

Nurtyasrini, S. \& Hafiar, H. (2016). Pengalaman komunikasipemulung tentang pemeliharaan kesehatan diri dan lingkungan di tpa bantar gebang. Diakses dari http://journal.unpad. ac.id/jkk/article/view/10437/5329. Jurnal Kajian Komunikasi Volume 4, No. 2, Desember 2016 hlm 119 - 228.

Soekartawi. (1988). Prinsip dasar komunikasi pertanian. Universitas Indonesia.

Umniyati, N., Hadisiwi, P., \& Suminar, J. R. (2017). Pengaruh terpaan informasi riset melalui website www.ppet.lipi.go.id terhadap sikap mahasiswa mengenai penelitian. Diakses dari http://journal. unpad.ac.id/jkk/article/view/9076/5829. Jurnal Kajian Komunikasi, Volume 5, No. 1, Juni 2017 hlm 111-120.

Yin, K. (2013). Studi kasus: desain dan metode,. Jakarta Rajawali Pers.
Yusup, P. M. \& Subekti, P. (2010). Teori dan praktik penelusuran informasi (information retrieval). Jakarta: Kencana.

Yusup, P. (2012). Perspektif: manajemen pengetahuan informasi, komunikasi, pendidikan dan perpustakaan. Jakarta: RajaGrafindo Persada.

Yusup, P. M. \& Saepudin, E. (2017). Praktik literasi informasi dalam proses pembelajaran sepanjang hayat. Diakses dari http://jurnal.unpad.ac.id/jkip/article/ view/11387/6030. Jurnal Kajian Informasi dan Perpustakaan Vol.5 No.1, , 79-94.

Wilson, T. D. (2000). Recent trends in user studies: action research and qualitative methods. Information Research, 5(3) Available at: http:// informationr. net/ir/53/paper76.html. . (2000). Human information behavior. Special Issue on Information Science Research, 3 (2). 